\title{
A divisão política da língua: um olhar a partir de narrativas fílmicas
}

Gesualda dos Santos Rasia ${ }^{1}$

\begin{abstract}
This article proposes to debate about the implications of materialistic assumptions in the act of thinking about issues related to the emergence of different linguistic registers in the social body. The linguistic diversity is considered here from a political dimension, the social division of the subjects, the language and the meanings produced by it. Difference does not emerge unrelated to dissent, which brings to debate the fruitful discussion between language and class struggle. The discursive materialities that we analyze to problematize the power relations in which linguistic uses are inserted, are clippings of filmic narratives. Taking these materialities into consideration, questions such as the status of language in spaces of resistance are formulated with regard to the following elements: linguistic diversity and the ideal of correction, the diversity of uses and exclusion of speaking subjects, and the imaginary that constitutes the written and formal uses in literate societies. This set of questions underlies, as a point of convergence, the political dimension of language, an element that we understand as nodal in the debates that guide language as an object of teaching.
\end{abstract}

Keywords: Language; class struggle; political; film narratives.

Resumo: Este artigo se propõe a debater acerca das implicações de pressupostos materialistas para se pensar questões atinentes à emergência de diferentes registros linguísticos no corpo social. A diversidade linguageira é considerada, aqui, desde uma dimensão política, da divisão social dos sujeitos, da língua e dos próprios sentidos por ela produzidos. A diferença não emerge desvinculada do dissenso, que traz ao debate a discussão, sempre profícua, entre língua e luta de classes. As materialidades discursivas que analisamos para problematizar as relações de força nas quais os usos linguísticos estão inseridos são recortes de narrativas fílmicas. A partir delas são pautadas questões como o estatuto da língua em espaços de resistência; a diversidade linguageira e o ideal de correção; a diversidade de usos e exclusão dos sujeitos falantes e o imaginário que constitui os usos escritos e formais nas sociedades letradas. A esse conjunto de questões subjaz, como ponto de convergência, a dimensão política da língua, elemento que entendemos nodal nos debates que pautam a língua enquanto objeto de ensino. Palavras-chave: Língua; luta de classes; político; narrativas fílmicas.

A vida não podia ser assim, sempre, uma repetição doida! (Conceição Evaristo, Becos da memória)

1 Professora na Universidade Federal do Paraná, é doutora em Teorias do Texto e do Discurso. 


\section{A colocação do problema}

O que significa dizer que a língua é politicamente dividida? Se tomarmos o político no sentido que lhe confere Rancière (1996, p. 39), de que

[...] aqueles que não têm direito de serem contados como seres falantes conseguem ser contados e instituem uma comunidade pelo fato de se colocarem em comum o dano que nada mais é que o próprio enfrentamento, a contradição de dois mundos alojados num só [...],

as diferenças usualmente concebidas como negatividade assumem feição positiva, e passam a demarcar assunção dos que não têm vez e voz. É acerca disso que nos ocupamos neste artigo, primeiramente, com a construção de um trajeto, pela via de estudos discursivos de feição marxista, que reflete sobre os processos de segmentação dos valores associados aos diferentes registros linguísticos no corpo social. Na sequência, mobilizaremos recortes de materialidades fílmicas que têm a questão do dissenso acerca da língua como pauta, sob o filtro do rastreamento teórico que fizemos.

\section{A questão da língua: uma querela marxista sempre atual}

O debate acerca da relação linguagem sociedade tem um marco instaurador de discursividades no Ocidente, na década de 60, com os estudos labovnianos. A pesquisa de Labov $^{2}$ nas lojas de departamento de Nova Iorque, bem como sobre os falares dos negros da periferia de cidades americanas, colocou em cena aspectos que sempre instigam à reflexão. Outro espaço-tempo de debate profícuo sobre a relação pautada foi o contexto soviético entre as décadas de 20 e 30 do século XX. Estamos falando de um entorno histórico cujo pano de fundo é a Revolução Socialista, a qual teve como questão central a disputa de forças entre o proletariado e os grandes proprietários. As questões de linguagem se colocaram, na sequência, como aspecto constitutivo para configurar alterações propostas na conformação social. Esse debate diz(ia) respeito ao estatuto ocupado pela língua nas relações infra e superestruturais, mais especificamente, na luta de classes.

No estudo de que ora nos ocupamos, optamos por considerar o contexto soviético das décadas de 20 e 30 como baliza para nossas reflexões, não apenas por uma questão de ordem cronológica, mas especialmente pelo caráter assumidamente político que o debate acerca da relação linguagem-sociedade assume nesse contexto e também pelos desdobramentos específicos que institui.

Sériot (2012) explicita que, para além dos propósitos práticos da União Soviética dos anos 20, de criar alfabetos e de instrumentalizar as línguas recentemente literalizadas, o projeto linguístico da época tinha como questão de fundo a passagem de uma "psicologia individual" para uma "psicologia social", por conta da valorização do coletivo em detrimento do individual. A língua, neste caso, manifestava-se como vínculo que definia os grupos. O pensamento hegemônico, de então, era o de que a língua constituía-se como uma superestrutura, com caráter de classe, portanto, modificando-se na medida das alterações na base econômica. Esse postulado, defendido, sobretudo pelo linguista Nicolai

2 Referimo-nos aqui ao estudo feito pelo linguista acerca do dialeto utilizado pela maioria dos jovens negros da periferia de cidades como Nova Iorque, Boston, Detroit, entre outras, e cuja questão central era se haveria uma relação entre o uso do dialeto (o Black English Vernacular) e os problemas de leitura apresentados por esses jovens na instância escolar. A outra pesquisa foi realizada em lojas de departamento de Nova Iorque, com o objetivo de avaliar a relação entre o emprego das diferentes formas do /r/, nesses espaços, pelas atendentes, e o aspecto da estratificação social. 
Marr, preconizava a língua nacional, enquanto unidade, como uma ficção, no que era avalizado por Lênin, ao afirmar que "em cada língua há duas línguas, assim como em cada nação há duas nações". Contudo, Sériot (op. cit.) assinala uma questão que, na passagem dos anos 20 para os anos 30, produz questões a serem respondidas: no que consiste mesmo a definição de social, que ancoraria a distinção entre "língua de classe" e "língua literária da classe hegemônica", esta última, a do "povo inteiro"? No limite, estaria em causa a noção mesma de povo. $\mathrm{O}$ autor traz à baila a problemática posta a partir da proposição de uma totalidade indivisa, e sintetiza a questão do seguinte modo:

A nação, na época stalinista, depois brejneviana, é constituída como um espaço político homogêneo, não contraditório, não dividido em grupos antagônicos, não clivado, em perfeita sincronia consigo mesmo, onde os indivíduos estão em fusão total com o grupo, sem agrupamentos internos, sem intermediários, e em divisão absoluta com um outro pensado como sendo perfeitamente externo. É uma nova topologia que se cria: um proletário russo é, assim, russo antes de ser proletário, enquanto nos anos 20 era o contrário (p. 30-31).

Na esteira dessa concepção, ganham respaldo as posições de defesa da integridade e não contaminação da língua materna. Vale lembrar que este postulado tem travessado a história dos diferentes povos, indelevelmente relacionada a questões de poder. É assim que o grego da era clássica estabeleceu-se como língua de arte e de cultura, vindo sua primeira gramática a configurar-se como modelo da boa escrita e de paradigmas flexionais de palavras ao abrigo dos ditos "barbarismos." Esse mesmo estatuto foi construído pelo latim, quando da ascensão e expansão do Império Romano, apenas para citar dois exemplos emblemáticos no Ocidente. No caso específico do contexto soviético, Sériot (op. cit., p. 32) aponta que, a partir do final da década de 30, a proposição de um "povo inteiro", homogêneo, portanto, vai estar relacionada àquele que supostamente vai falar a língua única da nação: a "língua russa literária"'. E o autor apresenta a dimensão paradoxal que o estabelecimento da língua única vai assumir:

Se existem línguas é porque existe o "um" (Milner, 1978)3, mas os limites do "um”, nos textos soviéticos, podem se tornar estranhamente imprecisos, do mesmo modo que a hierarquia das inclusões é bastante elástica: se "um" é incluído em um "um" mais amplo, as "línguas", depois dessa operação de inclusão, são rapidamente chamadas de "dialetos" (SÉRIOT 2012, p. 44).

$\mathrm{O}$ estatuto de língua manifesta-se, portanto, na emergência da fratura que produz a divisão política, ainda que obliterada pela tentativa impossível de homogeneização. Nas palavras do autor, "o ideal de transparência revela uma opacidade assustadora" (p. 46).

Nos anos 50, a pauta acerca do estatuto representado pela língua nos embates tecidos entre as relações de classes é retomada no contexto soviético, marcada, especialmente, por uma série de questionamentos acerca da atualidade do pensamento de Marr, publicados no Pravda 4 . É nesse contexto que é publicado texto de Stálin, na forma de perguntas e respostas, intitulado "Sobre o marxismo na linguística", no qual ele defende o caráter superestrutural da língua.

3 MILNER, J. C. L'amour dela langue. Paris: Seuil, 1978.

4 Principal jornal da União Soviética e um órgão oficial do Comitê Central do Partido Comunista da União Soviética entre 1918 e 1991.

5 A publicação data de 20 de junho de 1950. 
A emergência desse debate é emblemática por conta das transformações pelas quais a sociedade soviética passara. O eixo do debate encontrava-se centralizado na figura de dois personagens: Josef Stálin e Nicolas Marr. Ambos, membros do partido comunista, concebiam a relação língua-ideologia de diferentes modos. Para Marr, a língua nacional, por estar circunscrita ao âmbito da superestrutura, gozaria de diferenciações de classe em cada formação social, assim, haveria a língua dos burgueses e a língua dos proletários, por exemplo. Inversamente, para Stálin, a língua seria instância alheia às determinações de classe, uma vez que ela não é uma superestrutura. O postulado stalinista encontrava-se assentado nos argumentos de que a língua não é criada por uma só classe, para satisfazer às suas necessidades, mas por todas as classes da sociedade ao longo de centenas de gerações; bem como estaria a serviço, indistintamente, de diferentes regimes. $\mathrm{O}$ apagamento do caráter de classe desfaz, de certo modo, a ideia de uma biunivocidade entre a ordem da língua e a ordem do real, como se as fronteiras do social pudessem ser delimitadas pela via do linguístico e vice-versa. Por outro lado, impõe uma simetria entre os homens e suas línguas, como se nem mesmo houvesse as tais fronteiras internas. Contudo, quando Stálin afirmou, em seu ensaio "Sobre o Marxismo na linguística", de 1950, que

[...] a língua, como meio de os homens se comunicarem entre si na sociedade, serve paralelamente a todas as classes da sociedade e manifesta sob esse aspecto uma espécie de indiferença relativamente às classes. Mas as pessoas, os diferentes grupos sociais, as classes, estão longe de ser indiferentes à língua. (SÉRIOT, op. cit., p. 6),

tornou possível que sua perspectiva de homogeneidade linguística que atravessava a proposição do "grande russo" tivesse um ponto de desestabilização. Tanto é que Balibar 6 (apud PECCHEUX, 1988, p. 91-92) retoma a tese de Stálin, aspeando a palavra indiferença e acrescentando que, ao contrário, as classes utilizam a língua "de modo determinado, no campo de seu antagonismo, especialmente de sua luta política". Pêcheux mobiliza a releitura de Balibar para destacar o fato de que a não "indiferença" das classes em relação "à língua se traduz pelo fato de que todo processo discursivo se inscreve numa relação ideológica de classes."7

O que Pêcheux está demarcando, neste caso, é a dimensão discursiva da língua, a mesma que possibilita a emergência do político, dimensão esta negada em uma visão totalitária de língua, conforme Sériot (op. cit., p. 49b), e que vai contra o fato de que "vários discursos possam compartilhar a mesma língua".

Este debate nunca deixou de produzir seus efeitos nas diferentes sociedades e em diferentes momentos históricos, sempre que irrompem no tecido social questões nas quais a materialidade linguageira dos sujeitos vai para a cadeira dos réus. Só no Brasil tivemos, a título de exemplo, três eventos emblemáticos disso: a implementação do último Acordo Ortográfico ${ }^{8}$, o dissenso acerca de livro didático publicado pelo $\mathrm{MEC}$, com respaldo

6 BALIBAR, Étienne. "Marxisme et linguistique”. Cahiers marxistes-leninistes, 1966, n. 12-13, p. 21-2.

7 Grifos do autor.

8 O Acordo Ortográfico da Língua Portuguesa é um tratado internacional firmado em 1990 entre os sete países de língua portuguesa destes países, os quais a utilizam como língua oficial. No Brasil entrou em vigor plenamente em janeiro de 2017. Seu objetivo explicitado foi o de criar uma ortografia unificada para o português, a ser usada por todos os países de língua oficial portuguesa. Em que pese a aparente ausência de dissensos, suscitou e suscita questões atinentes a aspectos econômicos e sobretudos políticos implicados em sua formulação. 
sobre variante linguística falada ${ }^{9}$ e o Manual do Politicamente Correto, proposto pelo ex-presidente, Luis Inácio Lula da Silva ${ }^{10}$. As querelas que envolvem registro linguístico ou mesmo a ordem do significado, como foi o caso da Cartilha, trazem à tona as fraturas que são da ordem do social e que demarcam a não indiferença das classes em relação à língua. No que tange aos registros linguísticos, entendemos que se trata de uma questão que pode e deve ser pensada como o próprio da divisão política da língua que traz a lume uma ferida sempre aberta: os códigos utilizados pelos que têm pouco ou nenhum acesso à escolarização é a marca mesma que delimita seu não-pertencimento, a condição de usufruto dos bens da cultura. Contradição esta, assim definida por Zandwais (2012, p. 181): "Para que seja considerado realmente de direito, precisa ser um sujeito falante capaz de compreender uma língua que deve ser sua, mas que não é bem sua..."

\section{A língua em cena}

Conforme trabalhamos na seção anterior, a discussão sobre o estatuto da língua na luta de classes, no contexto soviético, sempre esteve envolta em polêmica, e seus principais pensadores não conseguiram produzir respostas cabais a partir das premissas que construíram. Contudo, foi justamente pelo não fechamento das questões que a querela marxista tem sua atualidade e produtividade em qualquer contexto no qual se paute a língua em relação aos jogos de forças da sociedade. É assim que trazemos à baila, a partir de agora, um conjunto de recortes de narrativas fílmicas que versam sobre questões de língua, a partir de diferentes perspectivas, porém, com pontos de convergência.

Recortamos para análise, excertos dos filmes Budapeste (2009), direção de Walter Carvalho; Entre les murs (2008), direção de Laurent Cantet e Narradores de Javé (2003), direção de Eliane Caffé. Neste conjunto, miramos a emergência de discursividades que materializam a relação escrita/oralidade; os valores sociais de diferentes registros linguísticos e o acesso/conhecimento de determinadas normas. A partir destes gestos procuramos produzir efeitos de convergência entre aquilo que enlaça as narrativas no que elas têm em comum: a divisão política da língua no corpo social.

\section{Budapeste: no 'amor à língua' do outro, as exclusões daquela que me pertence}

O filme "Budapeste", de 2009, é uma adaptação de obra homônima de Chico Buarque, dirigido por Walter Carvalho. A narrativa tem como um dos motes a entrada do ghost-writer José Costa em uma experiência espaço-temporal na cidade de Budapeste, onde adentra o hermetismo do idioma húngaro, que aprende investido de um legítimo "amor pela língua". Esse espírito se manifesta na cena em que o personagem se encontra em um bar e trava diálogo com um nativo que chega e pede ao atendente um maço de cigarros:

9 Em 2011, a comunidade de falantes da língua portuguesa no Brasil, entre especialistas e leigos, foi envolvida no debate/confronto de diferentes posições expressas a partir da distribuição para as escolas públicas, pelo MEC, do livro didático "Por uma vida melhor", da autora Heloísa Ramos. A polêmica derivou do fato de a autora ter defendido, no livro, a legitimidade de usos populares da língua em suas formas orais, apresentando, inclusive, exemplos.

10 Em 2004, o então presidente da República, Luiz Inácio Lula da Silva, publica, em nome da Secretaria nacional de Direitos Humanos, um manual que apresenta, com a respectiva definição, um rol de palavras e expressões consideradas ofensivas ao outro marcado por condição histórico-social de minoridade ou fragilidade. A Cartilha, designada "Politicamente Correto e Direitos Humanos", teve, em 2005, repercussão polêmica, considerada como tentativa de cerceamento dos usos da língua, o que seria próprio de um estado totalitário, assim como dos sentidos produzidos pelos sujeitos. 
Recorte n. 1

a) cena localizada entre os minutos $33: 07-38: 37$

José Costa está em uma livraria, tentando decifrar as difíceis palavras do idioma húngaro. Lá, se depara com Kriska, moça nativa que o interrompe de sua concentração, retira-lhe a revista que ele tinha em mãos, acenando negativamente:

- O húngaro não se aprende em livros.

- Não?!

- Não. Dizem que é a única língua que o Diabo respeita.

Saem juntos da livraria e segue uma tentativa de diálogo a partir de significantes aleatórios que vão surgindo e dos quais Kriska vai dizendo a versão em húngaro. Ela vai ensinando palavras nesse idioma para José, demandadas pelo contexto do contato entre os dois. José Costa esforça-se para aprender, na mesma medida em que vai se estabelecendo um clima de cumplicidade e afeto entre os dois. No decurso do contato a moça lhe diz:

- Você vai aprender. Vou te dar meu idioma.

Ambos sentam-se em um banco. José acende um cigarro que tira de uma carteira na qual consta a palavra "fecskë" (andorinha), que ele lê, pronunciando a primeira vogal como /e/, ao que ela o corrige, produzindo um "a" central.

\section{b) cena localizada entre os minutos 1:10 - 1:13}

(Nativo) - Eu quero um maço de cigarro. Facskë, por favor.

(José Costa) - Não é Facsksë. Se fala Fecskë (andorinha)"

(Nativo) - Como é que é? Te conheço?

(José Costa) - Não é Facskë. Se fala Fecskë!! Que é a pronúncia correta em húngaro.

(N) - Quem é você pra me corrigir? Um estrangeiro. O húngaro é meu território.

(JC) - Posso ser um estrangeiro... mas não costumo maltratar meu idioma como você!

(N) - Como assim?

(JC) - Facskë...

(N) - Estou maltratando o húngaro? Minha língua materna?

(JC) - Sua língua materna?

(N) - Sim! Minha língua materna!

(Dono do bar) -Parem com isso! Vão acabar destruindo meu bar!

(JC) - Tudo bem! Tudo bem!

(Dono) - Sobrevivi aos alemães, aos russos, e agora vocês?

(N) - Tudo bem, tudo bem.

(Dono) - Os dois têm razão: é fecskë aqui em Budapeste e facskë na terra Székly.

(N) - Ponto.

E dirigindo-se a José Costa:

- Desculpa.

Os dois começam a rir e concordam que as duas formulações são possíveis. Saem abraçados e José ensina ao nativo palavras pertencentes ao baixo calão do português.

O personagem José Costa é o próprio narrador do romance e também da adaptação fílmica, cuja questão-mote, desenroladora dos demais fatos, se dá no intervalo de tempo em que José Costa precisa ficar involuntariamente em Budapeste, na Hungria, e aí se debate com questões atinentes à sua identidade cultural. Resultado de problemas com um voo da Turquia para o Rio de Janeiro, a escala longa em Budapeste o faz deparar-se a outra 
versão de seu nome - Kosta Zsoze -, contígua a outra versão de si mesmo, assim como com uma língua nada comum e a qual ele se desafia a aprender:

Kosta Zsoze progressivamente, mediante seu novo convívio social, modificará sua narrativa/existência, elaborada em prosa, na língua portuguesa, para uma narrativa/existência poética, em húngaro. Melhor dizendo, ele faz um curioso percurso de narrador inexistente, enquanto um ghost writer que escreve, mas não se assume como autor, para um narrador existente que escreve seus poemas que, no entanto, acabam não sendo publicados em seu nome (NAPUTANO; JUSTO, 2016, p. 1).

José Costa está dividido entre dois países, dois amores e duas línguas, ao mesmo tempo em que perfaz um percurso para reconhecer-se e ser reconhecido como escritor, adentrando o universo da língua-outra. E ele o faz de modo contraditório, situando-se no entremeio de práticas e posições antagônicas. $\mathrm{O}$ aprendizado da língua-vida se sedimenta nas trocas amorosas que tem com Kriska, que utiliza, inclusive, algumas formas do dialeto székly ${ }^{11}$, a exemplo da palavra fecskë. Ainda, ele faz transcrições para um professor que é estudioso dessa variante. Contudo, estabelece como imaginário uma língua afeita a um padrão imutável e que não aceita ser maltratado, como na cena no bar. O personagem projeta na língua húngara feição de objeto de amor, como se fora sua língua materna, por um lado e, ao mesmo tempo, estabelece-a como condição de acesso à cultura do outro. Essa dupla projeção é explicitada por Sériot (2012) quando este autor reporta ao estabelecimento da "grande língua russa" como objeto de amor:

O amor pela língua materna pode nascer da leitura de uma gramática, que conjuga, então, num mesmo movimento, o amor e o conhecimento do objeto estudado [...] Porém, resultado do estudo, o amor pela língua é ao mesmo tempo uma condição de acesso ao objeto (SÉRIOT, 2012, p. 32-33).

O desejo de aprendizagem da língua do outro, impulsionado por uma necessidade premente, gera essa forma de amor nos termos de Milner (1975), a logofilia que despreza o que não cabe na régua de parâmetros do correto e aceitável. Imaginariamente, para o personagem a apreensão do registro "acertado" irá lhe fornecer a outorga da língua. Ele não percebe que a língua viva depara-se com ele dia após dia, jogando com significados e significantes, e pela via mesma da relação amorosa com Kriska, que procura deslocá-lo da rigidez das formas pré-estabelecidas para "dar-lhe" a língua viva. E nisso contraria a crença de que seria o húngaro a "única língua que o Diabo respeita", assim como a frase de elogio proferida pelo poeta Kocsis Ferenc em um encontro de escritores: “- Única, intacta, intraduzível." José Costa insiste em manter o húngaro numa condição de imutabilidade, vendo, contudo, sucumbir seu intento na cena em que sai do bar em que disputara a forma correta da palavra andorinha, em húngaro, com um nativo, acaba concordando com ele e, em troca, "entrega-lhe" palavras obscenas do português.

\section{Entre os muros da escola: a metáfora dos muros políticos e sociais}

O filme "Entre os muros da escola" tem como título original "Entre les murs"12, de autoria de François Bégaudeau e direção de Laurent Cantet. Foi lançado em 2008, na

11 Área histórica e etnográfica na Romênia, habitada principalmente por húngaros e romenos.

12 Versão completa disponível em: <https://www.youtube.com/watch?v=FgP404aQE4E. https://www.youtube. $\mathrm{com} /$ watch? $\mathrm{v}=\mathrm{FgP} 404 \mathrm{aQE} 4 \mathrm{E}>$ 


\section{Conexão Letras}

França $^{13}$. Estrelado por François Bégaudeau, que vive o personagem François Marin, professor de língua francesa em uma escola periférica de ensino médio, é uma espécie de microcosmo da França contemporânea, na medida em que tem como foco central uma sala-de-aula "caldeirão", com jovens de diferentes culturas, todas minoritárias e marginalizadas na pólis que os recebe sem acolher.

Estas são as condições imediatas de produção da narrativa: uma França contemporânea, notadamente xenófoba, com migrantes vivendo às suas margens físicas, econômicas, políticas e culturais. E, em que pesem os esforços de acolhimento de um professor que se trai no equívoco da imposição da norma culta, da língua das elites, sua relação com os alunos é marcada pelo jogo de forças, pela resistência manifesta na fala dos filhos desses migrantes, os quais se recusam a falar uma língua/registro que não lhes diz respeito e nem se traduz em sentido. Atentemos a um fragmento de diálogos em sala de aula, em que essa tensão se faz presente por ocasião da discussão em torno do funcionamento de tempos e modos verbais em francês:

\section{Recorte n. 2}

\section{Cena localizada entre os minutos 15:42 - 19:00}

Esmeralda: - Professor, por que "imperfeito do indicativo"? Por que não é só "imperfeito"?

Professor (ao mesmo tempo em que tenta aquietar a sala: - Boa pergunta, Esmeralda, por que é que dizemos "do indicativo"?

Esmeralda: - se eu soubesse não tava perguntando.

Professor: - Sim, tem razão. Alguém sabe por que especificamos imperfeito "do indicativo", e não apenas "imperfeito"?

(...)

Professor: - Se dizemos "imperfeito do indicativo", é para distinguir do outro imperfeito, que imperfeito é esse?

Agam: - É o imperfeito do subjuntivo.

Professor: - Exatamente, é o imperfeito do subjuntivo! Alguém pode me dar um exemplo do imperfeito do subjuntivo?

Khoumba: - Eu posso estar enganada...

Professor: - Eu acho que é bem possível.

Khoumba: - Eu estivesse.

Professor: - Eu estivesse, muito bem... Do verbo "estiver"?

Koumbha: - Não sei... "Eu estivava". "Eu estivesse”, "nós estivéssemos", "tu estivesses..."

Professor: - Não está mal, mas não está utilizando o verbo corretamente. Você tem alguma vaga lembrança da terminação do imperfeito do subjuntivo. Imaginem que eu digo: "É necessário que eu esteja ... em forma" O que é este "esteja" aqui? Eva?

Eva: - É o presente do subjuntivo.

Professor: - Muito bem, é o presente do subjuntivo. Se quisermos construir no imperfeito do subjuntivo temos que fazer a concordância dos tempos. Vou colocar aqui no passado: "Era necessário que eu estivesse em forma.

Esmeralda revida: - "Era necessário que eu estivesse em forma”. - Ninguém diz isso! - Ei, ei, vamos nos acalmar! "Era preciso que eu..." Khoumba? 
Khoumba: - "Fusse"...

Professor: - Fosse?

Esmeralda: - Você acha que eu vou falar pra minha mãe: "Era necessário que eu estivera"?

Professor: Não é "estivera". Aprenda primeiro a conjugar: "Era necessário que eu estivesse em forma".

Alguns alunos: - Ninguém diz isso!

Khoumba: - Eu tinha razão! Era "que eu estivesse!"

Professor: - Não é não. Será que posso responder a pergunta que me fizeram? Se é que estão interessados mesmo!

Outra aluna: - Eu autorizo.

Professor: - Percebo que antes mesmo de aprender o uso do imperfeito do subjuntivo já estão me dizendo que ele não serve para nada. Primeiro, aprendam. Depois, questionem o uso dele. Preste atenção no que está escrito aqui.

Khoumba: - Eles têm razão, porque as pessoas não falam assim hoje em dia. Nem mesmo minha avó fala assim. Nem seu bisavô!

Agam: - Isso é da Idade Média!

Professor: - Não é nada da Idade Média.

Khouma: - É algo burguês! Qual foi a última vez que ouviu alguém falar assim?

Professor: - Ontem, entre amigos, usamos o imperfeito do subjuntivo.

Agam: - Não, alguém normal!

(...)

O argumento do professor - "Primeiro aprendam e depois questionem sobre o uso" -, não convence os alunos, aliás, gera reações de agressão física na classe, rebeldia esta que pode ser sintoma da impossibilidade de estes alunos ocuparem efetivamente um lugar social, de elaborarem o pertencimento social pela ordem da língua e, por consequência, o reconhecimento como sujeitos de direito.

Os esforços envidados por Marin para que os alunos aprendam o idioma francês e os embates inerentes a esse processo demarcam as posições em que os sujeitos se inscrevem na Formação Social ${ }^{14}$. O professor, enunciando do lugar de cidadão branco, nativo, apesar de sua empatia para com a precariedade das condições sociais dos estudantes, "esquece" que a proposição de adentramento à ordem da língua, de parte deles, pela via das formas normatizadas e distantes dos usos quotidianos produz efeito de imposição de um "processo civilizatório". A norma congelada, ausente de realidade, pautada no princípio da evidência que justifica a especificação "indicativo" como diferente do "subjuntivo", por exemplo, nada significa para adolescentes latinos, árabes, asiáticos, africanos e latino-americanos, todos moradores da periferia parisiense.

A proposição da língua homogênea, de parte do representante do Aparelho Institucional Escolar ${ }^{15}$, produz, assim, tentativa de silenciamento de discursividades. Primeiro, pelo efeito de apagamento das identidades múltiplas e de suas respectivas discursividades. E,

14 A noção de Formação Social (FS), referida em Michel Pêcheux (1975) entrelaçada à noção de Formação Ideológica (FI), pode ser compreendida a partir de uma leitura do marxismo já relido por Althusser, no qual ela "designa uma sociedade específica, como articulação específica de modos de produção, um dos quais exerce um papel dominante".

15 A escola foi definida como AIE (Aparelho Ideológico de Estado) por Althusser (1985), na medida em que se trata de instância empírica na qual se materializam as práticas do Aparelho Repressivo do Estado. Estes, segundo o autor, "funcionam principalmente através da ideologia, e secundariamente através da repressão, seja ela bastante atenuada, dissimulada, ou mesmo simbólica." (Althusser 1985, p. 71). 
contíguo a esse aspecto, o apagamento também dos diferentes modos como esse estrato social-cultural acessa a língua francesa.

Contudo, não há ritual sem falhas, valendo-nos, aqui, de postulado pêcheuxtiano (1988). O processo ideológico de naturalização pelo qual o sujeito-professor é tomado é posto em suspense diante da emergência do real da história no real da língua quando do questionamento de Khoumba.

A noção de real da língua, cunhada por Milner (1978, p. 20), remete ao reconhecimento do "impossível próprio da língua", "irrepresentável" mas que, de modo paradoxal, é continuamente objeto de cercamento e circunscrição de parte de linguistas e gramáticos. Gadet e Pêcheux (2004, p. 30) pautam essa problemática afirmando que a questão do real da língua "inscreve-se nessa disjunção maior entre a noção de uma ordem própria à língua, imanente à estrutura de seus efeitos, e a de uma ordem exterior, que remete a uma dominação a conservar, a reestabelecer ou a inverter".

Fazem parte esse impossível, sempre extraditado para fora dos limites do que se considera aceitável como língua, os registros linguísticos que identificam sujeitos à margem da cultura letrada ou inseridos nela mas que a questionam, de seu interior mesmo, como é o caso da personagem Khoumba.

Milner (op.cit., p. 27) afirma o movimento do impossível de língua propondo que "a língua em si não é nada mais do que essa divisão considerada em geral, uma língua é uma forma particular desta divisão: um dialeto de uma língua, uma reorganização específica de uma divisão particular". A noção de real desponta, assim, como "o impossível eu lhe é próprio" (op. cit., p. 52). Gadet e Pêcheux (2004, p. 52) acolhem a tese de Milner, porém, submetem-no à relação com a história e assim afirmam: "tentamos aqui fazer trabalhar o real da história como uma contradição da qual o impossível não seria foracluído".

A flexão verbal que Khoumba faz é o próprio real da língua, que irrompe pela via da contradição histórica, posto que é o ponto de corte que denuncia que a língua não é una e indivisível, mas tão fragmentada quanto a sociedade em suas divisões e dissensos. A escola, contudo, mantém-se em uma esfera de irrealidade, enquadrando suas práticas de ensino de língua em formatos que traduzem a dimensão política da língua. Com isto, assume visibilidade a divisão que denuncia a "parcela dos sem-parcela", nos termos de Rancière (1996). E é assim que os muros da escola, título da narrativa, acabam por simbolizar a segmentação traçada entre o interior do espaço escolar em relação à sua exterioridade social, assim como as barreiras internas que os estudantes desaparelhados precisam transpor para serem reconhecidos no lócus que supostamente os acolhe.

\section{Narradores de Javé: a emergência política dos registros orais}

O filme "Narradores de Javé16" é um drama brasileiro, dirigido por Eliane Caffé e tem como questão central a construção de uma alternativa, de parte dos moradores do Vale de Javé, para manter a existência da cidade e de sua memória diante da iminência de alagamento do povoado em decorrência da construção de uma hidrelétrica.

Marcados pelo analfabetismo, os moradores da cidade concluem, a partir de conversa no coletivo, que precisam criar um fato de relevo e reconhecimento pelo olhar outro - o das autoridades - na tentativa de garantirem sua permanência e continuidade. Constatam

16 O filme ganhou 3 prêmios no Festival do Rio, nas seguintes categorias: Melhor Filme - Júri Oficial, Melhor Filme - Júri Popular e Melhor Ator (José Dumont). Também Recebeu o Prêmio da Crítica no Festival Internacional de Friburgo, realizado na Suíça. 
que o Vale possui um valor épico, pautado na história de sua fundação; contudo, não goza de reconhecimento, pois encontra-se diluído no âmbito da oralidade que se perpetua na memória coletiva. É assim que entabulam diálogo, em reunião no espaço da única igreja da cidade, com os moradores, discutindo sobre a necessidade de alçamento do teor das narrativas orais ao estatuto científico:

Recorte n. 3

\section{Cena que vai do minuto 7:05- 12:31}

- É isso mesmo, gente, vão construí a barragem, Javé tá no caminho das água. Logo isso aqui tudo vira represa!

O povo se agita com a notícia, todos falam ao mesmo tempo, indignados, ao que Zaqueu, um líder comunitário, afirma:

- Nós vamo tê que saí!

Uma das moradoras, apoiada por outros, assevera: "Ah, não pode. A gente não pode saí da nossa casa!"

Zaqueu chama seu Valdo, que esteve junto na reunião com as autoridades, para explicar os fatos à comunidade:

- Os engenheiro abriro os mapa na nossa frente e explicaram tudinho nos pormenor. Tudo com os numbro, as foto, um tantão delas. E explicaram prá gente os ganho e os progresso que a usina vai trazê. Vão tê que sacrificá uns tantos, prá beneficiá a maioria. A maioria eu não sei quem são, mais nóis é que somo os tantos do sacrifício. Não é não, Zaqueu?

Zaqueu explica, diante do tumulto gerado pela afirmação:

- Eu perguntei pros home se não tinha nada prá gente salvá Javé das água, que se tivesse, a gente ia fazê.

Fermino, um dos moradores, pergunta:

- E aí, Zaqueu, tem jeito?

- Os home disseram que só não inundam quando a cidade tem alguma coisa importante, história grande, quando é coisa de tombamento, aí vira patrimônio e não mexem nela. (...) Aí me acendeu assim uma esperançazinha, porque si Javé tem algum valor, são as história das origem, os guerrero, lá do começo, que vocês vive contando e recontando! E isso, minha gente, isso é patrimônio, isso é história grande.

Maria Dinha pergunta, incisiva:

- E você disse isso pros engenheiro, Zaqueu? Desse jeito encaprichado que você tá dizendo agora?

- Eu não disse? Eu disse... Não adianto nada, não adiantô! Não adiantô nem eu conta que aqui tem muita terra, muita propriedade adquiridas só nas divisas cantadas.

Zaqueu sugere:

- Não seja por isso, então nós vamo todo mundo lá e cantamo.

(...)

Zaqueu, tentando acalmar os ânimos, acaba tendo uma ideia:

-Peraí, gente! Os homes disseram que só não inunda se for patrimônio. Não é assim? Então já sei o que a gente tem que fazê....

(Todos) - O que tem que fazê????!!!!!

- Até hoje ninguém escreveu, também porque não preciso, mais então vamo nóis mesmo, hoje, escrevê a grande história do Vale de Javé. 


\section{Conexão Letras}

As pessoas se entreolham, emudecidas e estupefactas com a proposta.

-Vamo colocá no papel os enredo, gente, desencava da cabeça os acontecimentos de valor. Botá na escrita, fazê um juntado de tudo que é importante, pa prová pas autoridade purque Javé tem que tê tombamento!

Maria Dinha concorda, comentando:

- Tá certo, história grande de valor é o que não falta aqui, não é minha gente?

Zaqueu replica:

- Só qui tem uma coisa...

- Eles falaro lá que só tem validade esse trabalho se for assim científico.

- Como assim, científico, Zaqueu?

- Científico é assim, que não pode ser essas patacoada mentirosa que cês inventam, essas patranha duvidosa que vocês gostam de dizê e contá.

Fermino revida:

- Peraí, Zaqueu, tudo que eu conto é caso acontecido!

Maria Dinha problematiza:

- E como vamo juntá as história, se tá tudo aí espalhado na cabeça do povo?

- E de quem é a mão santa que vai escrevinhá? Botá as letra no papel?

Silêncio momentâneo e inquieto entre o povo. Porém, num repente, Fermino, sentado na janela, sugere:

- Chama Antonio Biá!

É latente e evidente nas falas dos moradores a inscrição social e cultural dos sujeitos na ordem da língua. Primeiramente, pelo registro, com a multidão de marcas que distinguem sua fala daquelas socialmente legitimadas. Depois, pelo modo como se colocam discursivamente diante das injunções da ordem da escrita, dizendo acerca das representações imaginárias historicamente construídas por essa modalidade e também produzindo esforços para inscreverem-se no interior de suas regras e formulações.

A relação linguagem-sociedade, ocupação central dos estudos sociolinguísticos, tem sido objeto de diferentes disciplinas de estudo. Neste artigo nós a tomamos desde uma perspectiva discursiva, portanto, com especificidades de abordagem. Enquanto as abordagens sob o rótulo "sociolinguística" pressupõem a autonomia do sistema linguístico, para depois proporem a inter-relação com o mundo social, em que pese a submissão do primeiro ao segundo (PAGOTTO, 2006, p. 51), a perspectiva do discurso parte do pressuposto da necessária imbricação entre o sistema da língua e sua exterioridade, na medida em que os diferentes registros inscrevem social e politicamente os sujeitos, ao mesmo tempo em que funcionam como "resposta do grupo de locutores à coerção simbólica exercida pelo interlocutor na relação (presumida) que este último tem com a 'norma legítima' (ORLANDI, 1996, p. 122). Ao afirmar assim, Orlandi está se referindo à variação estilística, aspecto que nos interessa diretamente nesta reflexão e que produz escopo também para outras formas de variação, se considerado o valor que elas assumem sempre em relação ao outro-histórico, pautado pela autora em outro texto seu:

[...] o fato de que em qualquer sociedade, mas interessa-nos aqui a nossa, que é parte da cultura ocidental, e sofreu processo de colonização - a escrita marca uma relação particular do sujeito com a história e é uma forma de inscrever o sujeito na ordem social. Consideramos, pois, a relação entre a escrita e a oralidade como uma relação necessária, incontornável no domínio do simbólico, em nossa sociedade (ORLANDI, 2012, p. 169). 
Os habitantes de Javé, analfabetos em sua maioria, identificam-se com a ordem da oralidade, e é desse interior que se veem impelidos à necessidade de inscreverem-se na ordem da escrita como recurso possível para manterem a existência do Vale. Dizer de "um jeito encaprichado", como consta na pergunta de Maria Dinha, dirigida a Zaqueu, é um indício dos movimentos que se acredita devam ser feitos para a passagem de uma ordem à outra. Outro elemento imaginariamente demarcador da passagem diz respeito ao teor do que vai ser registrado. A comunidade reconhece o valor e a grandiosidade das narrativas que compõem a memória coletiva do povoado, no entanto, são advertidos por Zaqueu de que as histórias precisam ter "valor científico". As histórias, passadas de geração em geração, e com diferentes versões, gozarão de legitimidade se forem registradas a partir de uma suposta verdade (daí a disputa que se segue em torno das diferentes versões que circulam) e de um formato aceitável do ponto de vista da norma.

Orlandi (op. cit) explicita a diferença de estatuto da oralidade e da escrita a partir da produção, pela escrita, de um "artefato", a partir dos efeitos no real que essa prática produz enquanto gesto simbólico: "Quem fala não precisa da legitimação da autoria. Quem escreve tem que ter autoria atestada. Essa atestação produz um efeito pragmático de unidade, de precisão" (p. 173). É nessa perspectiva que a autora propõe que se desfaça a "oposição rígida entre e escrita e oralidade" e se pense em "funcionamentos discursivos - discurso oral e discurso escrito" (p. 176).

\section{Considerações Finais}

O sempre profícuo debate acerca da relação língua/sociedade/ideologia é apresentado por Sériot (2012) a partir da configuração de três corporeidades: a social, a material e a política. A língua tratada como corpo, por este autor, é o lugar de articulação dessas três dimensões. Corpo mal coberto, acrescentaríamos nós, posto que se apresenta revestido por um tecido esgarçado pela descontinuidade e desatamento de fios. Língua que materializa discursos investidos da vã tarefa de completude e totalização: a norma, a língua escrita, o apagamento das diferenças. Contudo, contraditória e constitutivamente, esse "resto", remendo que compõe o que, em tese, encontra-se à margem dos espaços legitimados insiste em aparecer, dar-se a ver e estabelecer-se.

Esse movimento foi traçado, neste estudo, a partir de recortes de narrativas fílmicas, trazendo ao debate um mosaico de questões usualmente pautadas no âmbito do ensino. E, neste caso particular, filmes que foram por nós trabalhados em contexto de sala aula com alunos do período inicial do Curso de Letras. Se os enredos são tramas fictícias ou reelaborações de acontecimentos da ordem da realidade, as tramas e tensões que abordam os movimentos da língua em sua relação com a história não o são.

Cena emblemática disso é aquela, no filme "Entre os muros da escola", quando o professor atende os pais individualmente para apresentar e discutir sobre problemas específicos dos estudantes. O irmão e a mãe de Souleymane, aluno africano, estão sendo atendidos e somente o primeiro interage com o professor, pelo fato de a mãe desconhecer o idioma francês. Com os olhos voltados para baixo, ela escuta do filho a tradução das falas do professor, as quais comenta em seu idioma, para o filho, que as traduz para o professor (1:00:19). Mulher imigrante que, a julgar pela proficiência linguística dos filhos, já se encontra há bom tempo em território francês. Contudo, continua fora, sem ter acessado a língua e, consequentemente, também as formas de juridismo do Estado que a interpela sobre a relação do filho com a Escola. A mãe imigrante "está sem pertencer", 


\section{Conexão Letras}

estatuto este que não raro é o dos sujeitos da escolarização, os quais formalmente estão inseridos na instituição, mas dela se veem segmentados pela divisão política instituída pela língua. A mesma divisão que separa a fronteira entre os sujeitos do discurso da oralidade e do discurso da escrita, consoante o filme "Narrativas de Javé". Divisão imaginária estabelecida também entre a língua que se deseja aprender e apreender em sua suposta incorruptibilidade, na esteira da narratividade de "Budapeste". Segmentações e exclusões as quais expõem, na fratura mesma que delineiam, a visibilidade dos que estão alijados, pela língua, da participação nos processos históricos. A parcela dos sem-parcela, que resiste, para que "A vida não seja, sempre, uma repetição doida!"

\section{Referências}

BUDAPESTE. Direção Walter Carvalho. Produção Rita Buzzar. Rio de Janeiro: Nexus Cinema e Vídeo, 2009.

ENTRE os muros da escola. Direção Laurent Cantet. Paris: Haut et Court, 2008.

GADET, F.; PÊCHEUX, M. A língua inatingível: o discurso na história da linguística. Campinas: Pontes, 2004.

LABOV, W. Padrões Sociolinguísticos. São Paulo: Parábola Editorial, 2008. Tradução: Marcos Bagno et al.

MILNER, J.-C. O amor da língua. Porto Alegre: Artes Médicas, 1978.

NAPUTANO, M.; JUSTO, J. S. Budapeste, de Chico Buarque, na narrativa da psicologia social construcionista. FRACTAL, Rev. Psicol., Rio de Janeiro, v. 28, n. 1, jan./ abr., 2016, p. 127-133.

NARRADORES de Javé. Direção Eliane Caffé. Rio de Janeiro: Bananeira Filmes, 2003.

ORLANDI, E. A linguagem e seu funcionamento. Campinas: Pontes, 1996. 2012. . Discurso em análise: sujeito, sentido, ideologia. Campinas: Pontes Editora,

PAGOTTO, E. G. Sociolinguística. In: PFEIFFER, C. C.; NUNES, J. H. (Org.). Introdução às ciências da linguagem: linguagem, história e conhecimento. Campinas: Pontes, 2006, p. 49-72.

PÊCHEUX, M. Semântica e Discurso: uma crítica à afirmação do óbvio. Campinas: Ed. Unicamp, 1988.

. "Só há causa daquilo que falha ou o inverno político francês: início de uma retificação". In: PÊCHEUX, M. Semântica e discurso. 4. ed. Campinas: Editora da Unicamp, 1988, p. 269-281. Trad. Eni Orlandi et al.

RANCIÈRE, J. O desentendimento. São Paulo: Editora 34, 1996.

SÉRIOT, P. “Língua, poder e corpo". In: ZANDWAIS, A. (Org.). História das ideias: diálogos entre linguagem, cultura e história. Passo Fundo: Editora da UPF, 2012.

ZANDWAIS, A. "Subjetividade, sentido e linguagem: desconstruindo o mito da homogeneidade da língua”. In: ZANDWAIS, A. (Org.). História das ideias: diálogos entre linguagem, cultura e história. Passo Fundo: Editora da UPF, 2012.

Recebido em: 16/04/2018 Aceito em: 01/06/2018 